\title{
Litho-stratigraphic and Hydrogeological Evaluation of Groundwater System in Parts of Benin Metropolis, Benin City Nigeria: The Key to Groundwater Sustainability \\ *10MOROGIEVA, OM; ${ }^{2}$ IMASUEN, OI
}

\author{
${ }^{I}$ Department of Physical Sciences, Faculty of Science, ${ }^{2}$ Department of Basic Science, Faculty of Basic and Applied Sciences, \\ Benson Idahosa University, Benin City, Nigeria \\ ${ }^{2}$ Department of Geology, Faculty of Physical Sciences, University of Benin, Benin City, Nigeria \\ Tel: $+2348036801978+234807331325$ \\ *Email: oomorogieva@biu.edu.ng,okpeseyi.imasuen@uniben.ed
}

\begin{abstract}
Previous studies revealed that soil properties play a significant role in aquifer contamination. Consequently, it is necessary to understand the nature and properties of soil in carrying out groundwater evaluation. This study evaluates the subsurface geology and groundwater flow direction in Okpagha, Iguomo, Ikhueniro and Okhuahe suburbs in Benin City, Nigeria. Six boreholes were drilled by means of manual (rotary) method in different parts of the study area and each borehole was logged in order to understand the lithology, depth to water table, static water level as well as flow direction. The results obtained show that aquifer within the study areas were confined, semi confined to unconfined and was dominated by sands with minor clay and lignite interbed. It was observed that aquifer becomes shallower towards eastern portion of the study areas with increase in sand and decrease in clay materials. It was also observed that groundwater flow map revealed a flow direction of North-West to South-East from North West to South East. The decrease in the depth of aquifer and increase in sand material could be explained by the closeness to sea level. This phenomenon can enhance the infiltration of contaminants into aquifer thereby contaminating the groundwater bodies. It is therefore necessary to constantly monitor the groundwater quality in this suburbs in order to be aware of the quality of water resources being consumed because poor water quality can impact public health negatively. Furthermore, the authors advise that boreholes should be drilled in the direction of groundwater flow for maximum yield
\end{abstract}

DOI: https://dx.doi.org/10.4314/jasem.v22i2.20

Copyright: Copyright $\left({ }^{\circ} 2018\right.$ Omorogieva and Imasuen. This is an open access article distributed under the Creative Commons Attribution License (CCL), which permits unrestricted use, distribution, and reproduction in any medium, provided the original work is properly cited

Dates: First received 15 May 2017; Received in revised form 27 January 2018; Accepted 10 February 2018

Keywords: Groundwater, lithology, borehole, aquifer, water quality and contaminants

In early 80 s to about mid-90s, government was solely in charge of public water supply both in the cities and in some rural communities of Nigeria. In a situation where pipe born water is not available, streams, rivers and in some case, mobile tank serve as alternative means for water supply. In the late 90s till date, private borehole became dominant due to government inability to meet up with her responsibility of providing water for the teeming population. Consequently, the number of individual boreholes increased sharply to the point that some owners convert their individual boreholes to serve commercial purpose. In Benin City and neighbouring communities for instance, it is difficult to find a house without a private borehole. Omorogieva et al., (2016); Akujieze and Oteze (2007) observed that some aquifer are shallow and subject to groundwater contamination especially in areas of high anthropogenic activities were there is no clay materials acting as seal to the infiltrating contaminants while Onyeobi and Akujieze (2014) reported that soil and sediments have a role to play in groundwater contamination. Imasuen et al., (2016) observed that sediments within Benin metropolis is of Miocene to Recent in age and are rich in accessary minerals like Tomaline, Zircon, Kynite, Rutile, Staurolite and Garrnet which indicate that the parents material is igneous and metamorphic origin. It was observed that in that report that the grain size is coarse to medium sand very well sorted to moderately sort. When wastes are not properly managed, the emanating leachate escape and percolates into groundwater through the soil medium to cause serious environmental and public health problems since waste contain hazardous materials (Imeokparia et al., 2009; Imasuen and Omorogieva, 2013a). Therefore, it is imperative to understand the lithological characteristics of the subsurface soil and groundwater flow pattern and the contaminants plume direction in order to properly site boreholes as this will help increase groundwater protection and sustainability for the benefit of mankind. Ikhueniro

*Email: oomorogieva@biu.edu.ng,okpeseyi.imasuen@uniben.ed 
and environs are suburb with high human influx and anthropogenic activities. The current study is aimed at characterizing the lithology of the soil by drilling boreholes randomly across the study areas; determine the static water level and groundwater flow direction. The study is highly significant because Omorogieva et al., (2016); reported that some aquifer in some parts of the study area are shallow and consequently impacted with the contaminants contained in the percolating leachates from a nearby dumpsite within the locales. The study will be valuable to local drillers and government in making policy gear towards environmental sustainability and groundwater protection for sustainable development.

\section{MATERIALS AND METHODS}

The study areas include Okpagha, Iguomo, Ikhueniro and Okhuahe suburb in Benin City, Edo state (Fig. $1)$.

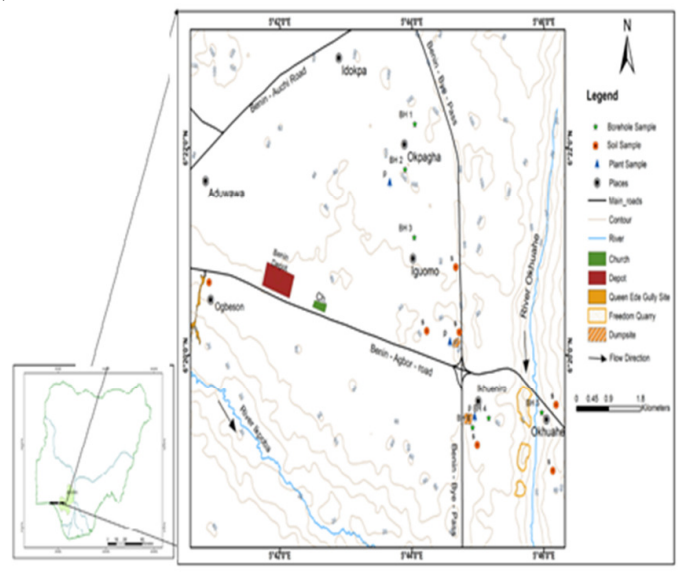

Fig. 1: Map showing the study location with borehole position in green colour

Edo State has a population of 3,233,366 and total land area of 19,794sq.km according to Edo State Bureau of Statistics (2013); National Population Commission (1996). The state lies approximately between latitudes $5^{\circ} 44^{\prime} \mathrm{N}$ and $7{ }^{\prime} 37^{\prime} ' \mathrm{~N}$ and between longitudes $5^{\circ} 44$ and $66^{\prime} 43^{\prime \prime} \mathrm{E}$ and share common boundaries with Kogi State in the north, Ondo State to the west, Delta and Anambra States to the east and north east respectively (Seibert, 2000; Osaghae, 1998). Seven (7) able bodied men, drilling bit and pipes, generator with connecting host, polythene bag for soil sample collection at interval of about 5 meters down hole, water tank for constant water supply as well as paper and pen for documentation. Six (6) boreholes were drilled randomly at different positions and depths in the study areas using rotary manual method of drilling. In the rotary method, the hole is drilled by a rotating bit to which a downward force is applied by able bodied men. The bit is fastened to, and rotated by, a drill string, composed of high quality drill pipe and drill collars, with new sections or joints being added as drilling progresses online assessment, (2015).

The cuttings are lifted from the hole by the drilling fluid which was continuously circulated down the inside of the drill string through water courses or nozzles in the bit and upward in annular space between the drill pipe and borehole. At the surface, the returning fluid (mud) is diverted through shale shakers, desilters, desanders and series of tanks or pits which treat the fluid. In the last of these pits the mud is picked up by the pump suction and repeats the cycle thereby making a connection, the process of adding a new joint of pipe to the drill string. As the downward force is applied, the bit cut through different strata. The different strata were logged as the bit cut down hole to the water bearing zone (aquifer) in order to determine the subsurface geology. The groundwater flow direction was determined by measuring the depth to water level in meter which is also known as static water level (SWL) and subtracted from the elevation above sea level (ASL) measured by Global Positioning System (GPS) in meter while in the field. The values obtained from the difference which is known as corrected water level (CWL) in meter were then plotted on a map to determine the flow direction. Arrows were used to indicate the flow direction on the map for easy understanding and evaluation.

Table 1: summary of borehole locations, SWL, Elevation and CWL for the study areas

\begin{tabular}{|c|c|c|c|c|}
\hline Latitude & Longitude & SWL (m) A & Elevation (m) B & CWL (m) B - A \\
\hline $06^{0} 21^{\prime} 07.9^{\prime \prime}$ & $005^{\circ} 44^{\prime} 2.7^{\prime \prime}$ & 60.32 & 112 & 51.68 \\
\hline $06^{0} 21^{\prime} 47.7^{\prime \prime}$ & $005^{\circ} 43$ '53.8."' & 60.32 & 111 & 50.68 \\
\hline $06^{0} 21^{\prime} 7.9$ ', & $005^{\circ} 44^{\prime} 2.2^{\prime}$ & 50.35 & 101 & 50.35 \\
\hline $06^{0} 19^{\prime} 23.2^{\prime}$ ', & $005^{\circ} 45^{\prime} 9.8^{\prime}$, & 47.6 & 82 & 34.1 \\
\hline $06^{0} 19^{\prime} 26.4^{\prime}$, & $005^{\circ} 45^{\prime} 58^{\prime}$, & 50.35 & 33 & -17 \\
\hline $06^{0} 19^{\prime} 17.7$, & $005^{\circ} 44^{\prime} 55.2^{\prime}$, & 50.35 & 92 & 41.64 \\
\hline
\end{tabular}




\section{RESULTS AND DISCUSSION}

Table 1 summarized the location, depth to water table as well as the static water level (SWL). The result revealed that SWL range from $47.6 \mathrm{~m}-60.32 \mathrm{~m}$ with a mean value of $53.22 \mathrm{~m}$. Borehole $\operatorname{logs}$ (Fig. 2-7) reveal four rock units; sand, sandy clay, clay and clay with lignite inter beds. The depth to water table shows an average depth of $88 \mathrm{~m}$ with deepest being $112 \mathrm{~m}$ at Okpagha and shallowest being $33 \mathrm{~m}$ at Okhuahe. Figure 8 show the correction of the entire borehole while Figure 9 shows groundwater flow map, borehole and dumpsite position. From the map, groundwater flow from north-west to south-east as indicated by the arrows on the groundwater flow map.

Table 1: Showing the Positions of Borehole, SWL, Elevation and Corrected Water Level for the study areas (Omorogieva, 2016)

The SWL observed in the study areas correspond with earlier work of Akujieze and Oteze (2007) which put the SWL in Benin on an average of $60 \mathrm{~m}$.

The aquifer becomes shallower towards Okhuahe indicating proximity to sea water level (SWL). Omorogieva et al., (2016); Isikhuemen and Omorogieva (2015a); Iyasele and Idiata (2012) demonstrated that shallow aquifers are subject to contamination especially when it lacks seal materials as clay to protect the groundwater.

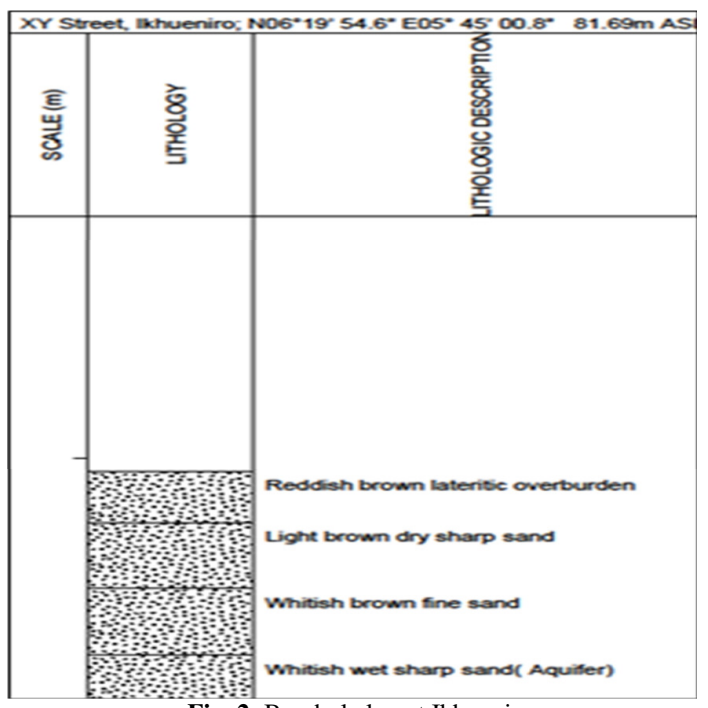

Fig. 2: Borehole log at Ikhueniro

Consequently, shallow aquifer particularly those close to anthropogenic activities have often been reported with poor water quality. Imasuen et al., (2016) observed that sediments in some parts of
Benin are porous and highly permeable and therefore make the groundwater vulnerable to contamination. This observation was not in contradiction to the current study especial in Okhuahe and Ikhueniro axis of the study. Furthermore, it was observed that boreholes sited at Okpagha and Iguomo where relatively deeper with clay materials acting as protective shield. However, the aquifer becomes shallow and shallower towards Ikhueniro and Okhuahe without any observation of protective shield such as clay.

This observation could be responsible for the poor water quality observed in the area (Omorogieva et al., 2016) and was further buttress by earlier report of Akujieze, (2014) which demonstrated that aquifers in Benin City are vulnerable to contamination.

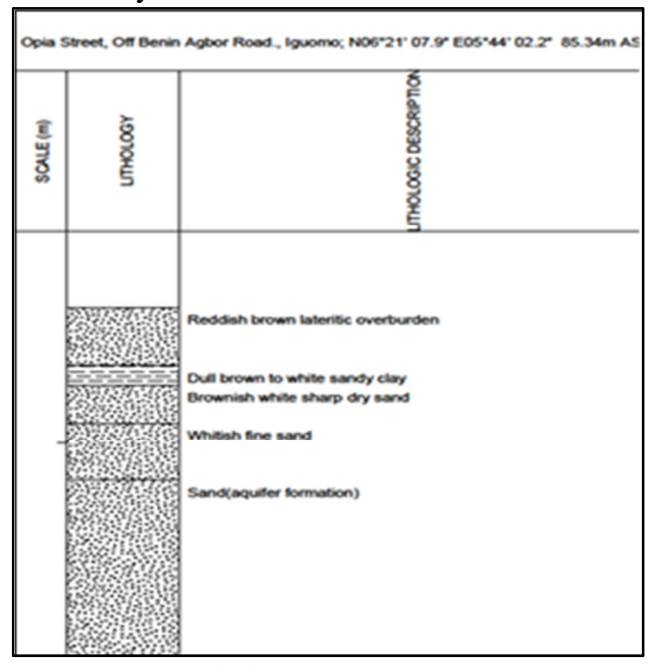

Fig. 3: Borehole log at Iguomo

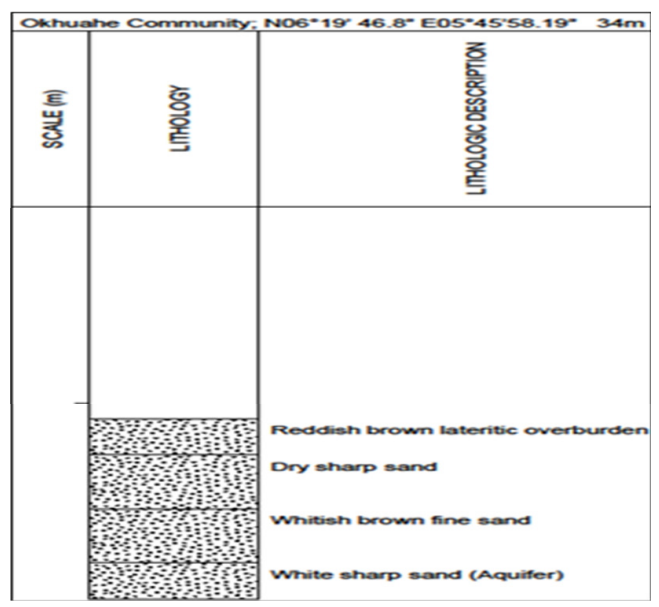

Fig. 4: Borehole log at Okhuahe 


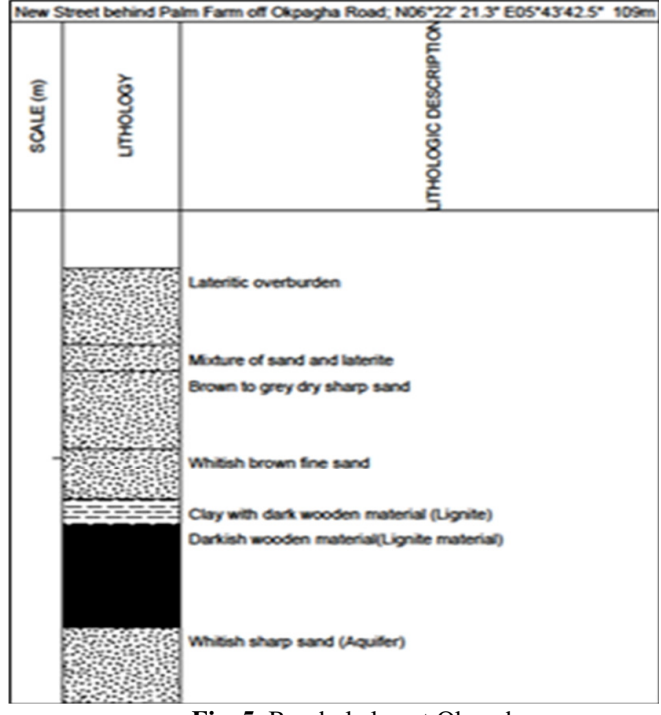

Fig. 5: Borehole log at Okpagha

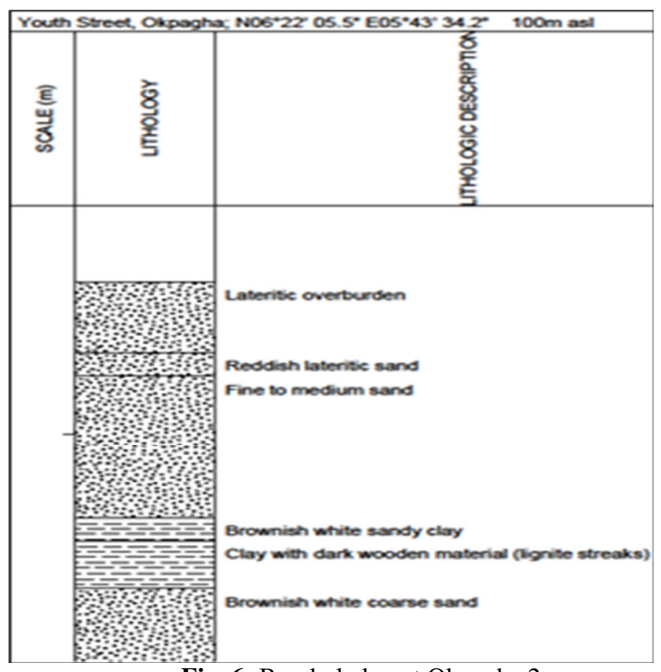

Fig. 6: Borehole log at Okpagha 2

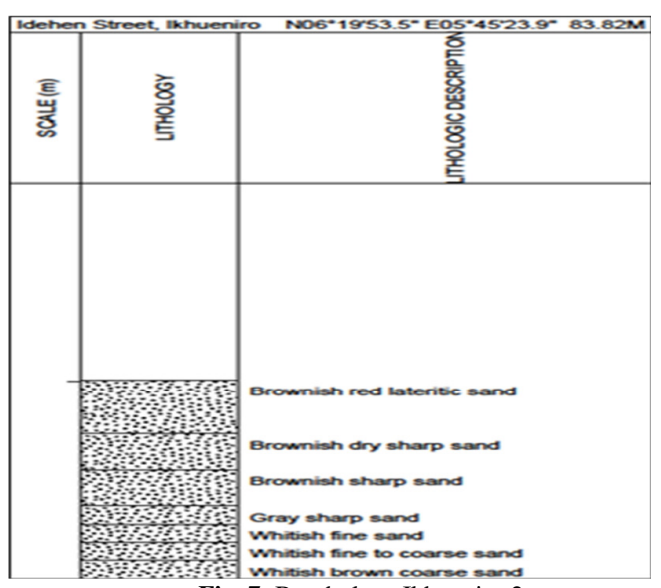

Fig. 7: Borehole at Ikhueniro 2

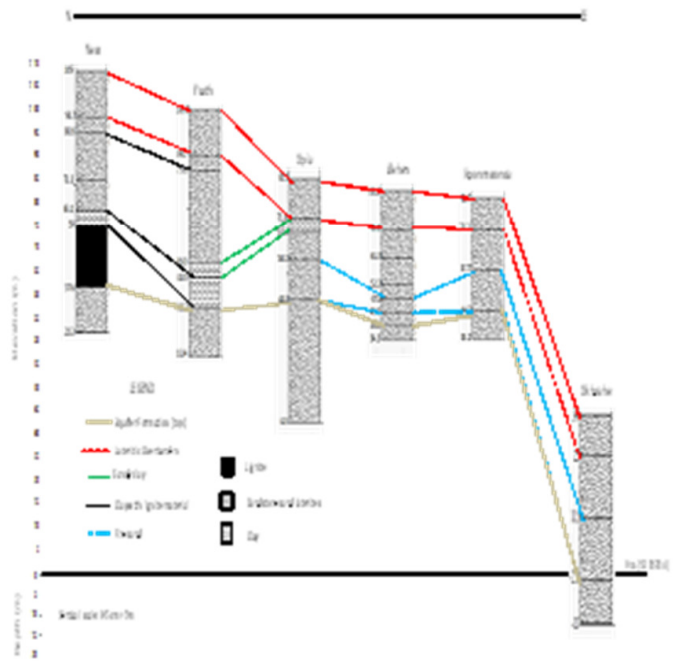

Fig. 8: Showing the correlation of litho logs of boreholes in the study areas

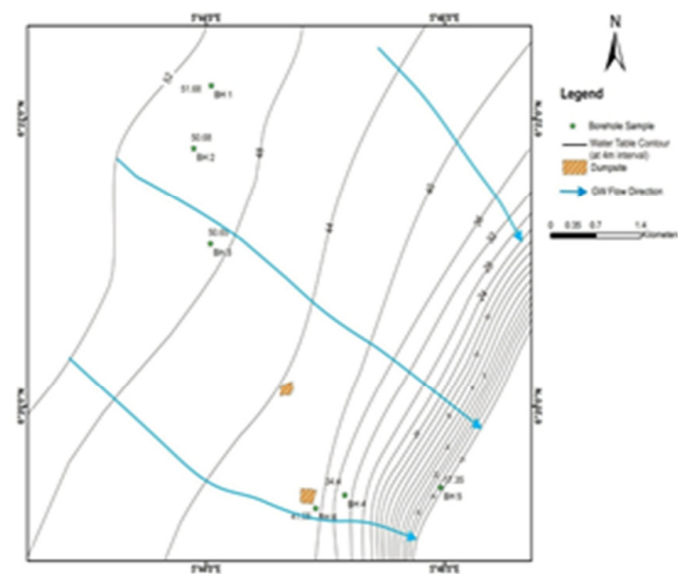

Fig. 9: Map showing groundwater flow direction

Onyeobi and Akujieze (2014) have earlier demonstrated that soils and sediments play a vital role in groundwater portability and hence recommended that it is essential to understand soil properties in groundwater studies. The soil properties couple with the depths to water level in this study indicates that there is a possibility of direct infiltration of the leachates emanating from the dumpsite into the aquifer in the south east portion of the study area hence, the poor water quality observed by Omorogieva et al., (2016). The interbeds of the thick dark woody materials at Okpagha indicates a geological boundary between Benin Formation (FM) and Ogwashi Asaba Formation (FM) which is characterized by plants materials (Reyment, 1965; Short and Stauble, 1967) and gradually thins away towards Okhuahe. Plume and flow direction indicate movement from the North West to South East 
direction which is in agreement with topographic and geologic nature of the terrain.

Conclusion: The study revealed four rock units (sand, sandy clay, clay sand and clay). Ikhueniro and Okhuahe are mainly of homogeneous rock unit, very well sorted to moderately sort sand with shallow aquifer subject to groundwater contamination. On the other hand, Okpagha and Iguomo are relatively deeper with four rock units of sand, sandy clay, clay sand and clay; consequently, the aquifer may not be vulnerable to contamination as a result of human influence but may be as a result of geologic factors. More boreholes need to be drilled within around Okpagha suburb in order to establish the observation reported in this study. Since groundwater flow from North West to South East, it advised that local borehole drillers should consider the flow direction for maximum yield while drilling deeper to avoid groundwater contamination as a result of human influence in Ikhueniro and Okhuahe suburbs. Ultimately, it is advisable that in the interim, groundwater sourced from Ikhueniro and Okhuahe suburbs areas of the study should be given a routine treatment before consumption following the guideline provided in World Health Organization (2007)

\section{REFERENCES}

Akujieze, CN (2004). Effects of Anthropogenic Activities on Urban Groundwater System and Aquifer Vulnerability Assessment in Benin City, Edo State, Nigeria. Unpublished Phd Thesis, University Of Benin

Akujieze, CN; Oteze, GE (2007). Deteriorating Quality of Groundwater in Benin City, Edo State, Nigeria. Journal of Nigeria Association of Hydrogeologists 1: 192-196

Edo State Bureau of Statistics (2013). The Edo State Statistical Year Book. Fourth edition produced by the State Central Office of Research and Statistics Pp131

Imasuen, OI; Omorogieva, OM (2013). Comparative study of heavy metals Distribution in Mechanic Workshop and Refuse Dumpsite in Oluku and Otofure, Edo, South-Western Nigeria. $J$ .Appl. Sci. Environ .Manage. 3 (17) pp425-430

Imasuen, OI; Omorogieva, OM (2013a). Sources and Environmental Implication of Heavy Metal Pollution In Plants Grown Around Contaminated Site In Edo State, Nigeria. Resource Journal in
Engineering and Applied Sciences: USA, 2(5) 385-391

Imasuen, OI; Omorogieva, OM; Nwokoloh, N.J (2016). Grain Size and Heavy Mineral Analyses of two Boreholes in Recent to Miocene Aquifer in Benin Formation. Nig. J. Technol. 354979 986

Imeokparia, EG; Onyeobi, TUS; Abodunde, FL (2009). Heavy Metals Concentration in the Soils from a Mechanic Village, Uvwie Local Government Area of Delta State. Nig. J. Appl. Sci. 27, 137-143

Isikhuemen, MI; Omorogieva, OM (2015a). Hydrogeology and Water Quality Assessment of the Middle Aquiferous Horizon of Onitsha and Environs in Anambra Basin, Eastern Nigeria. British J. Appl. Sci. Technol. 9(5) pp 475-483

Isikhuemen, MI (2014). The Hydrogeology of Onitsha and Environ. Unpublished M.Sc Thesis, University Of Benin, Benin City Nigeria 142pp

Iyasele, JU; Idiata, DJ (2012). Determining the Borehole Water Quality in Edo South and Edo North Areas of Edo State. Research Journal in Engineering and Applied Science

National Population Commission (2006). National Head Count (Census). National Office Abuja, Nigeria

Omorogieva, OM (2014). Geochemistry of some Heavy Metals in Contaminated Soils, Stream Sediments, and Plants; Sources, Environmental and Health Implications and Possible means of Remediation, Oluku and Environs as a Case Study. Unpublished M.Sc Thesis, Department of Geology, University of Benin, Nigeria, pp79

Omorogieva, OM; Imasuen, OI; Sanni, E.B (2013). Analysis and concentration of Heavy Metals; Mercury, Nickel, Arsenic, Lead, Chromium and Cadmium in a waste currency dumpsite: Sources, Its Environmental Implications. Journal of Science Research 12: 87-94

Onyeobi, TUS; Akujieze, CN (2014). Characteristics of Soil and Sediment Parameters of Jisik-Izombe Upper Aquifer System for Assessment of the Potential of Groundwater Pollution. J. Appl. Sci. Environ. Manage. Vol 18 (4) pp 677-683 
Osaghae, E (1998). The Crippled Giant: Nigeria Since Independence. Indiana University Press pp. 236 0-253-33410-1

Rayment, RA (1965). Aspects of the Geology of Nigeria. Ibadan University Press

Seibert, U (2000)."Languages of Edo State" University of Iowa Retrieved 2007-11-10
Short, KC; Stauble, AJ (1967) Outline of Geology of Niger-Delta; $A A P G$ Bu. V. 51 p761- 779.

WHO (2007). Water for Pharmaceutical Use. In: Quality Assurance of Pharmaceuticals: A Compendium of Guidelines and Related Materials. 2nd Updated Edn. World Health Organisation, Geneva, 2: 170-187

Rotary Method of Drilling ((2015). Accessed online on the $30^{\text {th }}$ October, 2015 at 3.34 am 